\title{
ONTOLOGIA MATEMATYKI WCZESNEGO HILBERTA
}

\begin{abstract}
ThE EARLY HiLbERT'S ONTOLOGY OF MATHEMATICS

Hilbert's views on the ontology of mathematics changed significantly between 1891 and 1904 Although his contributions to the foundations of mathematics in the years 1899-1904 paved the way for his later program of formalism, in the ontology of mathematics he was then still far from methodological nominalism associated with his mature formalism. Paradoxically, Hilbert's original position in the ontology of mathematics (from 1891) was that of conceptualism combined with constructivism. These two views were the philosophical basis for Brouwer's intuitionist attacks on Hilbert's account of the foundations of mathematics in the 1920s.

Keywords: Hilbert, ontology of mathematics, foundations of mathematics, conceptualism, constructivism
\end{abstract}

Pogląd Davida Hilberta na ontologię matematyki w okresie „dojrzałego” formalizmu (w latach dwudziestych XX w.) charakteryzuje się najczęściej jako nominalizm metodologiczny. Hilbert nie odmawiał odniesienia przedmiotowego odtworzonej formalnie matematyce, ale uważał, że w badaniach, przede wszystkim metamatematycznych, nie powinno się owej „treści” uwzględniać, jest ona dla nich nieistotna (Hilbert 1926: 170-171). Powstaje więc pytanie: jaką ontologię matematyki przyjmował Hilbert we wczesnym okresie swojej działalności? Czy zawiera się już tam zapowiedź nominalizmu metodologicznego, czy też zajmował on wtedy jakieś inne wyraziste stanowisko?

Już w latach 1899-1904 powstawały prace Hilberta z zakresu podstaw matematyki, które zwiastowały późniejszy program formalizmu. Omówiony tu zostanie również jeszcze wcześniejszy etap rozwoju filozofii Hilberta: w $1891 \mathrm{r}$. prowadził on w Królewcu wykład z geometrii rzutowej, a opublikowane współ-

* Katedra Filozofii Logiki, Wydział Filozoficzny, Uniwersytet Papieski Jana Pawła II w Krakowie, ul. Kanonicza 9, 31-002 Kraków, dada59@gmail.com. 
cześnie notatki do wykładu zawierają uwagi natury ontologicznej. W latach 1899-1900 powstały trzy ważne prace z zakresu podstaw matematyki. Chodzi o aksjomatyzację geometrii euklidesowej, aksjomatyzację arytmetyki liczb rzeczywistych i słynny wykład Mathematische Probleme wygłoszony na Kongresie Matematyków w Paryżu. Tu również można odnaleźć wskazówki natury ontologicznej. Co istotne, ostatnie dwie prace stanowią wyraźną zapowiedź programu formalizmu, bardzo zdecydowanie akcentując potrzebę dowodu niesprzeczności arytmetyki liczb rzeczywistych. Jeszcze dobitniej zapowiada program formalizmu wykład z 1904 r. wygłoszony na III Kongresie Matematyków w Heidelbergu. Zawiera on pierwszy szkic dowodu niesprzeczności arytmetyki liczb naturalnych. Także w tym tekście znajdują się odniesienia natury ontologicznej.

W artykule prześledzone i przeanalizowane zostaną wątki ontologiczne wspomnianych prac Hilberta. Jego teksty będą omawiane chronologicznie, co pozwoli zauważyć ewentualne przemiany ontologii matematyki. Należy pamiętać, że wątek ontologiczny nie był pierwszoplanowy w pracach, które zmierzają już do wykrystalizowania idei programu formalizmu.

\section{WYKŁAD GEOMETRII RZUTOWEJ 1891 - KONCEPTUALIZM I KONSTRUKTYWIZM}

Pierwsza znana refleksja Hilberta dotykająca w pewnym sensie zagadnienia ontologii matematyki pochodzi z semestru letniego $1891 \mathrm{r}$., kiedy prowadził on w Królewcu wykład na temat geometrii rzutowej (Hilbert 2004). Przeciwstawił sobie dwa typy dyscyplin matematycznych. Do jednej grupy - tzw. czystej matematyki - zaliczył m.in. teorię liczb, algebrę i teorię funkcji, a do drugiej, oprócz mechaniki i fizyki, włączył geometrię. Według Hilberta wyniki pierwszej grupy dyscyplin matematycznych można otrzymać na drodze czystego myślenia (durch reines Denken). Ów proces czystego myślenia polega na sprowadzeniu twierdzeń całej czystej matematyki do związków między liczbami naturalnymi. A więc liczba naturalna jest „tym” elementem (also die ganze Zahl ist das Element).

Stwierdzenia te zawierają w istocie dwie tezy, jedną dotyczącą systematyzacji (unifikacji) matematyki dziewiętnastowiecznej, drugą dotyczącą ontologii matematyki. Po pierwsze, Hilbert wypowiada tezę o arytmetyzacji matematyki dziewiętnastowiecznej, czyli o sprowadzeniu jej, dzięki wysiłkom Bernarda Bolzana, Augustina Cauchy'ego, Karla Weierstrassa, do arytmetyki liczb naturalnych. Druga teza mówi o tym, że podstawowym „budulcem” ma- 
tematyki w jej aspekcie ontologicznym $-\mathrm{w}$ związku z arytmetyzacją matematyki - jest liczba naturalna.

Hilbert stwierdza dalej, że do pojęcia liczby naturalnej można dojść przez czyste myślenie, „przeliczając” własne myśli (indem ich die Gedanken selber $z a ̈ h l e)^{1}$. Konieczne są tutaj dwie uwagi. Po pierwsze, wydaje się, że Hilbert pozostaje pod wpływem lektury pracy Was sind und was sollen die Zahlen? Richarda Dedekinda, który starając się ugruntować arytmetykę liczb naturalnych, odwoływał się do „mojego świata myśli” (meine Gedankenwelt). Po drugie, powyższe stwierdzenie Hilberta wskazuje, że jego zdaniem liczby naturalne są konstruktem ludzkiego myślenia. Drugie twierdzenie też byłoby $\mathrm{w}$ istocie zbieżne $\mathrm{z}$ poglądem Dedekinda na ontologię liczb naturalnych (Dedekind 1888: §73)². Połączenie drugiego twierdzenia z wcześniejszą tezą Hilberta, że liczba naturalna jest podstawowym i w istocie jedynym „budulcem" matematyki czystej, prowadzi do konstatacji, że stał on w 1891 roku na stanowisku konstruktywizmu.

Ten wniosek można wzmocnić dalszym, mocnym stwierdzeniem Hilberta z 1891 r. Otóż po rozważaniach na temat matematyki czystej, przechodzi on do przeciwstawienia geometrii wspomnianemu typowi matematyki. Stwierdza, że nie można ugruntować własności przestrzeni - czym właśnie zajmuje się geometria - przez czyste myślenie (nimmer durch blosses Nachdenken ergründen). A jest tak zdaniem Hilberta dlatego, że przestrzeń nie jest wy-

${ }^{1}$ „Geometria jest naukq o własnościach przestrzeni. Różni się ona zasadniczo od dyscyplin czysto matematycznych, jak np. teoria liczb, algebra, teoria funkcji. Wyniki tych dyscyplin mogą być uzyskane na drodze czystego myślenia, w ten sposób, że stwierdzane stany rzeczy można sprowadzać, na drodze jasnych logicznych wnioskowań, do prostszych, tak długo, aż w końcu potrzebne jest wyłącznie pojęcie liczb naturalnych. Każde, najbardziej glębokie i skomplikowane twierdzenie matematyki czystej musi ostatecznie być sprowadzalne do relacji między liczbami naturalnymi 1, 2, 3, ... . Ponieważ jednak droga ta jest długa i trudna, sięgnięto do środków, które ją upraszczaja i skracaja albo zabezpieczaja ją przez podziat na etapy itd. Jednak owo sprowadzenie jest nie tylko możliwe, lecz także zalecane. Dzisiaj twierdzenie uważa się za udowodnione dopiero wtedy, gdy ostatecznie wyraża ono pewną relację między liczbami naturalnymi. Zatem liczba naturalna jest tym elementem. Do pojęcia liczby naturalnej możemy także dojść przez czyste myślenie [w ten oto sposób, że ja] sam przeliczam myśli. Metody i podstawy matematyki czystej należą do czystego myślenia. Dalej, kiedy zajmuję się teorią liczb lub algebrą, nie potrzebuję niczego poza czystym logicznym myśleniem" (Hilbert 2004: 22).

2 Praca Dedekinda wywarła zasadniczy wpływ na refleksję młodego Hilberta dotycząca matematyki. Świadczy o tym chociażby stwierdzenie Hilberta z 1931 r.: „W 1888 r. jako młody docent $\mathrm{z}$ Królewca udałem się $\mathrm{w}$ podróż do kilku niemieckich uniwersytetów. W Berlinie we wszystkich matematycznych kręgach trwała wtedy dyskusja na temat wydanej właśnie pracy Dedekinda Was sind und was sollen die Zahlen? - w większości w tonie bardzo krytycznym. Dzieło to jest, obok badań Fregego, najważniejszą, pierwszą dogłębną próbą ugruntowania elementarnej teorii liczb naturalnych" (Hilbert 1931: 487). 
tworem naszego myślenia (es ist ja Raum nicht ein Produkt meines Nachdenkens)3.

Skoro geometria jest tu przeciwstawiana matematyce czystej, to trzeba wyciągnąć wniosek, że to, co jest przedmiotem czystej matematyki, jest, zdaniem Hilberta, właśnie wytworem naszego myślenia. A zatem podstawowy budulec matematyki czystej, czyli liczby naturalne, są konstruowane przez poznający podmiot, i dalej, konstruowane są z nich, przez ten sam podmiot, wszystkie inne przedmioty matematyki czystej. Należy też przyjąć, że same liczby naturalne i wszystkie skonstruowane $\mathrm{z}$ nich przez podmiot obiekty matematyki czystej istnieją właśnie w myśli podmiotu. Tak było w tradycji konstruktywistycznej, począwszy od Immanuela Kanta, który łączył konstruktywizm z konceptualizmem. W każdym razie Hilbert nie wskazuje innego „miejsca” istnienia matematycznych konstruktów ludzkiej myśli - np. czegoś w rodzaju późniejszego „trzeciego świata” Karla Poppera - co przemawia za tym, że trzyma się w tej kwestii zastanej tradycji, potwierdzonej przez Dedekinda.

Hilbert zawarł w swym tekście z $1891 \mathrm{r}$. również pewne wskazówki, jak należy pojmować przedmioty, którymi zajmuje się geometria. Dyscyplina ta zajmuje się przestrzenią i jej własnościami. Przestrzeń i jej własności dane są podmiotowi poznającemu przez zmysły. Przestrzeń nie jest - jak wspomniano - wytworem myślenia poznającego podmiotu. Stwierdzenia te wykluczają kantowskie pojmowanie przestrzeni. Przestrzeń wypełniona materią stanowi natomiast przedmiot badań fizyki (Hilbert 2004: 22).

Podsumowując ontologiczne aspekty tekstu Hilberta z 1891 r., należy stwierdzić, że w kwestii ontologii matematyki czystej stał on na stanowisku konstruktywizmu i konceptualizmu. Prawdopodobnie mamy tu do czynienia z wpływem myśli Dedekinda. Natomiast przedmiotem geometrii była dla niego istniejąca „na zewnątrz” podmiotu poznającego, uchwytna za pomocą zmysłów przestrzeń fizyczna.

Nie sposób powstrzymać się tu od stwierdzenia, że Hilbert, który w latach dwudziestych XX w. był w permanentnym sporze z Brouwerem, wynikającym m.in. z konceptualizmu i konstruktywizmu twórcy intuicjonizmu, w 1891 r. zajmował w kwestii ontologii matematyki stanowisko niezwykle bliskie koncepcji Brouwera, zbudowanej w pierwszym dziesięcioleciu XX w. Warto tu

3 „Zupetnie inaczej postępuje się z geometrią. Nigdy nie mogę ugruntować własności przestrzeni na drodze czystego myślenia, tak samo jak nie mogę poznać w ten sposób podstawowych praw mechaniki, prawa grawitacji, ani jakiegokolwiek innego prawa fizycznego. Przestrzeń nie jest produktem mojego myślenia, lecz jest mi dana przez moje zmysty. Zatem potrzebuję moich zmysłów do ugruntowania własności przestrzeni. Potrzebuję oglądu i eksperymentu, tak samo jak potrzebuję ich przy ugruntowaniu praw fizycznych, gdzie dochodzi jeszcze materia jako dana przez zmysty" (Hilbert 2004: 22). 
podkreślić, że w dotychczasowych badaniach dorobku Hilberta jego wczesny konstruktywizm i konceptualizm nie zostały zauważone.

\section{SYSTEM PRZEDMIOTÓW - 1899/1900}

W latach 1899-1900 powstały trzy prace Hilberta o ogromnym znaczeniu dla dziejów badań nad podstawami matematyki. Są to, w kolejności chronologicznej: Grundlagen der Geometrie (Hilbert 1899/1968), w której zawarta jest aksjomatyka geometrii euklidesowej i względny dowód jej niesprzeczności, Über den Zahlbegriff (Hilbert 1900a) z aksjomatyką arytmetyki liczb rzeczywistych i postulatem dowodu jej niesprzeczności i Mathematische Probleme, wykład wygłoszony w 1900 r. na II Międzynarodowej Konferencji Matematyków w Paryżu, zawierający - w wersji opublikowanej (Hilbert 190ob) - przegląd 23 najważniejszych nierozwiązanych problemów matematyki u progu XX w.

Prace te zawierają nowe akcenty w Hilbertowskiej ontologii matematyki. Zlikwidowany zostaje dotychczasowy rozziew między ontologią matematyki czystej i geometrii. Dokonuje się to m.in. kosztem odejścia w ontologii matematyki czystej od konstruktywizmu i konceptualizmu.

Klasyczny dla ontologii matematyki (geometrii) Hilberta z tamtego okresu jest fragment wprowadzenia do aksjomatyki geometrii euklidesowej:

Przedstawiamy sobie trzy różne systemy przedmiotów (Systeme von Dingen): przedmioty pierwszego systemu nazywamy punktami i oznaczamy za pomocą $A, B, C$. Przedmioty drugiego systemu nazywamy prostymi i oznaczamy za pomocą $a, b, c$. Przedmioty trzeciego systemu nazywamy płaszczyznami i oznaczamy za pomocą $\alpha, \beta, \chi[\ldots]$. Przedstawiamy sobie punkty, proste i płaszczyzny w określonych wzajemnych związkach, wyrażanych przez takie słowa, jak leżeć, pomiędzy, przystający, równoległy, ciągły [...]. Nic nie mówi się o tym, czym są te przedmioty. Wolno nam przedstawiać je sobie jakkolwiek - byle było to zgodne z następującymi po tej wypowiedzi aksjomatami4.

Stwierdzenie Hilberta pozostawia szerokie pole do interpretacji, by nie powiedzieć, spekulacji, na temat tego, czym są przedmioty geometrii euklidesowej. Nawiązując do ujawnionych preferencji Hilberta z 1891 r., trzeba stwier-

4 „Wir denken uns drei verschiedene Systeme von Dingen: Die Dinge des ersten Systems nennen wir Punkte und bezeichnen sie mit A, B, C. Die Dinge des zweiten Systems nennen wir Geraden und bezeichnen sie mit a, b, c. Die Dinge des dritten Systems nennen wir Ebenen und bezeichnen sie mit $\alpha, \beta, \chi[\ldots]$ Wir denken die Punkte, Geraden und Ebenen in gewissen gegenseitigen Beziehungen durch Worte wie liegen, zwischen, kongruent, parallel, stetig [...] Es wird nichts darüber gesagt, was die Dinge dieser Systeme sind. Wir haben die Freiheit uns darunter vorzustellen, was wir wollen - wenn es nur mit den Aussagen der dieser Erklärung folgenden Axiome verträglich ist” (Hilbert 1899/1968: 2). 
dzić, że przedmioty geometrii nie muszą być przedmiotami świata zewnętrznego w stosunku do podmiotu poznającego. Nie muszą też być przedmiotami konstruowanymi przez podmiot i zależnymi w swym istnieniu od niego.

Najogólniej można stwierdzić, że przedmioty geometrii euklidesowej mogą być jakimikolwiek przedmiotami, byleby ich trzy systemy (klasy) spełniały Hilbertowską aksjomatykę. Tę myśl można próbować wyrazić i w ten sposób: twórca teorii (Hilbertowskiej geometrii) nie proponuje żadnego modelu zamierzonego przedstawionej teorii (syntaksy). Dopuszczalne są różne modele.

Można - jak się zdaje - dopuszczać także inne interpretacje. Jedna z nich łączyłaby się z koncepcją przedmiotów abstrakcyjnych. Przedmiotem partykularnym geometrii (np. prostą) byłby - najogólniej - ten przedmiot, którego zbiór własności byłby teoriomnogościowym przecięciem zbiorów własności tych wszystkich przedmiotów, które w przynajmniej jednym modelu aksjomatyki Hilberta byłyby interpretowane jako odpowiednik któregoś ze znaków $a, b, c, \ldots \mathrm{z}$ aksjomatów. To rozwiązanie z kolei sugerowałoby jednak pewien model zamierzony geometrii euklidesowej.

Ponieważ w późniejszym okresie swojej działalności naukowej Hilbert stanął na stanowisku metodologicznego nominalizmu, to można by też próbować dopatrywać się zapowiedzi takiego stanowiska w 1899 r. Można by twierdzić, że interesowała go w istocie syntaktyka, teoria z jej znakami $A, B, C$, $\ldots, a, b, c, \ldots, \alpha, \beta, \chi, \ldots$, natomiast nie interesowała go semantyka (to, co odpowiada tym znakom). Geometrię Hilberta można było uprawiać, nie uwzględniając jej zaangażowania ontologicznego. W każdym razie wprowadzenie do Grundlagen der Geometrie pozostawia - jak widać - szeroko zakrojone pole dla spekulacji natury ontologicznej.

Istotne jest, że w latach 1899-1900 Hilbert traktował przedmioty geometrii tak samo jak przedmioty matematyki czystej. Jesienią 1899 r. przedstawił historycznie pierwszą aksjomatykę liczb rzeczywistych. Pozostawała ona w istotnym związku z Hilbertowską aksjomatyką geometrii: aksjomaty ciągłości w obydwu sformułowane były tak samo. W ten sam sposób podchodził Hilbert do kwestii ontologii. Twierdzil, że liczby rzeczywiste to system (klasa) przedmiotów (ein System von Dingen), których wzajemne relacje dane są przez skończony i domknięty (abgeschlossene) system aksjomatów5. Nie podawał przy tym żad-

5 „IV 2. (Aksjomat zupełności) Do systemu liczb [rzeczywistych] nie jest możliwe dodanie innego systemu przedmiotów tak, by w powstałym w ten sposób systemie przedmiotów były spełnione równocześnie wszystkie aksjomaty I, II, III [chodzi o pewne zbiory aksjomatów] i aksjomat IV 1; lub krótko: liczby [rzeczywiste] tworzą system przedmiotów, który, przy zachowaniu wszystkich aksjomatów, nie może być w żaden sposób rozszerzony [...] Wątpliwości, które w ogóle były podnoszone co do istnienia całości wszystkich liczb rzeczywistych i co do istnienia wszelkich zbiorów nieskończonych, tracą wobec zaprezentowa- 
nej dalszej charakterystyki owych przedmiotów. Można jedynie przypuszczać, że liczbami rzeczywistymi są w jego ujęciu wszelkie przedmioty, które spełniają warunki nałożone przez aksjomaty. To pozostawia pole do takich samych hipotez natury ontologicznej jak w przypadku geometrii. W każdym razie niejasny do końca status ontologiczny przedmiotów matematyki czystej i geometrii został w 1899 r. zrównany. Poza tym, skoro obiekty arytmetyki (tutaj liczby rzeczywiste) nie muszą być konstruktami ludzkiej myśli i istnieć zależnie od podmiotu - są one bowiem dowolnymi przedmiotami spełniającymi aksjomatykę - to należy przyjąć, że również w ontologii matematyki czystej Hilbert odszedł od swego wczesnego konceptualizmu i konstruktywizmu.

Powstaje pytanie: skąd wzięło się zauważone wyżej zrównanie ontologii geometrii i matematyki czystej? Aby na to pytanie odpowiedzieć, należy wskazać, że w Grundlagen der Geometrie Hilbert przedstawił względny dowód niesprzeczności geometrii euklidesowej. Wskazał bowiem model tej geometrii w arytmetyce liczb rzeczywistych. Tym samym Hilbert pokazał, że również geometrię można zarytmetyzować, a więc zunifikować z tym, co w 1891 r. nazywał matematyką czystą. Skoro matematyka czysta i geometria stanowiły jedną „budowlę”, to status ontologiczny przedmiotów tych dyscyplin został z konieczności zrównany.

Teksty Hilberta z lat 1899-1900 zawierają jeszcze jedną wskazówkę dotyczącą ontologii matematyki. Chodzi o Hilbertowskie kryterium istnienia matematycznego. Hilbert nawiązuje do tego tematu w wykładzie Mathematische Probleme, gdy omawia postulat dowodu niesprzeczności aksjomatyki liczb rzeczywistych. Utożsamia tutaj przedmioty matematyczne z pojęciami, np. traktuje jako pojęcie liczbę rzeczywistą, której pierwiastek równy jest -1 . Hilbert stwierdza ogólnie, że jeśli można udowodnić, iż cechy przypisane pojęciu nie prowadzą przy „skończonej liczbie logicznych wnioskowan” do sprzeczności, to wtedy dowiedzione jest matematyczne istnienie pojęcia, np. liczby czy funkcji ${ }^{6}$.

nego wyżej ujęcia wszelką prawomocność: jako zbioru liczb rzeczywistych nie traktowaliśmy wyżej ogółu wszystkich możliwych praw, według których następują po sobie elementy jakiegoś ciągu podstawowego, lecz - właśnie jak to wyżej zostało przedstawione - jako system przedmiotów, których wzajemne relacje dane są przez wskazany wyżej skończony i domknięty system aksjomatów I-IV. Wypowiedzi o przedmiotach owego systemu mają ważność tylko wtedy, gdy można je wyprowadzić z aksjomatów na drodze skończonej liczby wnioskowań logicznych" (Hilbert 1900a: 183-184).

${ }^{6}$ „Kiedy pojęciu nadaje się własności, które są wzajemnie sprzeczne, to twierdzę: to pojęcie matematycznie nie istnieje. Tak np. nie istnieje matematycznie liczba rzeczywista, której kwadrat jest równy -1 . Kiedy jednak udaje się udowodnić, że nadane pojęciu własności nigdy nie mogą prowadzić, przy zastosowaniu skończonej liczby logicznych wnioskowań, do sprzeczności, to twierdzę, że w ten sposób udowodnione jest matematyczne istnienie tego pojęcia, np. liczby lub funkcji, która spełnia pewne warunki” (Hilbert 190ob: 265). 
Trzeba jednak stwierdzić, że jedno z przytoczonych stwierdzeń stoi w sprzeczności z ontologicznymi uwagami Hilberta poczynionymi przy okazji wprowadzenia aksjomatyki geometrii i aksjomatyki arytmetyki liczb rzeczywistych. Twierdził on tam, że obiektem geometrii czy też liczbą rzeczywistą może być dowolny przedmiot spełniający warunki aksjomatyki. Natomiast sposób wprowadzenia kryterium istnienia matematycznego sugeruje, że przedmiotami matematyki mogą być jedynie te przedmioty, które są pojęciami.

Podsumowując wypowiedzi ontologiczne Hilberta z lat 1899-1900, trzeba podkreślić, że zrównuje on status ontologiczny przedmiotów matematyki czystej i geometrii. Obiektami matematyki są wszelkie przedmioty spełniające warunki nałożone przez aksjomatyki. Tym samym Hilbert odchodzi od swojego wczesnego konstruktywizmu i konceptualizmu. Takie ujęcie kwestii obiektów matematycznych pozostawia jednak szerokie pole do domysłów doprecyzowujących ontologię. Hilbert formułuje też swoje kryterium istnienia matematycznego: przedmiot $x$ istnieje wtedy i tylko wtedy, gdy $x$ jest niesprzeczny?.

\section{ONTOLOGIA W RAMACH ZAPOWIEDZI FORMALIZMU — $1904 \mathrm{R}$.}

W latach 1899-1900 Hilbert zapowiadał dowód niesprzeczności arytmetyki liczb rzeczywistych. Zagadnienie to uważał za jeden z najistotniejszych problemów matematyki u progu XX w. W wystąpieniu na III Międzynarodowym Kongresie Matematyków w Heidelbergu (1904) zatytułowanym Über die Grundlagen der Logik und der Mathematik (Hilbert 1905) przedstawil pierwszy szkic dowodu niesprzeczności arytmetyki liczb naturalnych. Zmiana przedmiotu zainteresowania z liczb rzeczywistych na liczby naturalne wynikała z odkrycia przez Russella antynomii w systemie logicznym Fregego, a to na tym systemie miała być nadbudowana arytmetyka liczb naturalnych.

Co istotne, tekst Hilberta z 1904 r. jest ważnym zwiastunem niektórych elementów budowanego dwadzieścia lat później programu formalizmu. Poddaje on badaniu formuly, ciągi skończone znaków, starając się wykazać, że $\mathrm{w}$ analizowanym systemie formalnym nie wystąpią formuły sprzeczne. Przy czym nie odróżnia jeszcze explicite języka przedmiotowego od metajęzyka, nie odróżnia matematyki i metamatematyki. Rodzi się tutaj interesujące z ontologicznego punktu widzenia pytanie, czy Hilbert w swej zapowiedzi

\footnotetext{
7 Owo kryterium również stanowi argument za odejściem Hilberta od konstruktywizmu. We wszelkich konstruktywizmach niesprzeczność obiektu jest jedynie warunkiem koniecznym istnienia obiektu. Konstruktywiści jako drugi warunek dodają konstruowalność obiektu.
} 
formalizmu z 1904 r. antycypował też nominalizm metodologiczny, istotnie związany z dojrzałym formalizmem lat dwudziestych.

Pierwsza odpowiedź brzmi: nie. Ale wymaga ona, rzecz jasna, istotnych dopowiedzeń. Na początku swojego szkicu dowodu niesprzeczności Hilbert wyraźnie przyjmuje, że będzie mówił o przedmiotach (Ding) oraz że przedmioty te będą oznaczane przez znaki (Zeichen). Wyraźnie odróżnia więc przedmioty od oznaczających je znaków. Chociaż dalej - w trakcie dowodu będzie posługiwał się znakami i budowanymi z nich formułami, to często zaznacza, że chodzi o przedmioty oznaczane przez znaki. Częściej jednak zamiast nazwy „przedmiot” (Ding), zadomowionej w jego tekstach, chociażby w omówieniach aksjomatyk z 1899 r., używa Hilbert terminu „przedmiot myślowy” (Gedankending). Podaje również jego dookreślenie: „przedmiot” (Gegenstand) naszego myślenia (unseres Denkens).

Powstaje pytanie, jak rozumieć podany termin. Zgodnie z narzucającą się interpretacją chodzi o przedmioty intencjonalne, czyli to, o czym myśli (może myśleć) podmiot. Inna interpretacja sugerowałaby, aby w przedmiotach myślowych doszukiwać się „,części”, ,elementów” procesu myślenia podmiotu. Ta druga interpretacja byłaby spójna z zakładanym przez Hilberta jeszcze w 1891 r. konceptualizmem i konstruktywizmem, zarzuconym jednak w latach 18991900. Do kwestii rozstrzygnięcia, które rozumienie jest tu odpowiedniejsze, przyjdzie nam jeszcze w tej pracy powrócić.

Hilbert wprowadza kombinacje znaków oznaczających przedmioty proste $(1,=)$ i stwierdza w istocie, że kombinacjom tych znaków odpowiadają kombinacje odpowiednich przedmiotów myślowych, będące też przedmiotami myślowymi (Gedankendinge). Następnie dzieli wszystkie tak zbudowane przedmioty na dwie rozłączne klasy: klasę (przedmiotów myślowych) istniejących (Seiende) i klasę (przedmiotów myślowych) nieistniejących (Nichtseiende) ${ }^{8}$.

\footnotetext{
8 „Przedmiot naszego myślenia nazywa się przedmiotem myślowym albo krótko przedmiotem i będzie oznaczany przez znak. Na początku naszych rozważań przyjmujemy przedmiot myślowy 1 (jeden). Zestawienie tego przedmiotu z samym sobą dwukrotne, trzykrotne lub wielokrotne, jak 11, 111, 1111 nazywamy kombinacjami przedmiotu 1 z samym sobą; tak samo nazywamy kombinacje owych kombinacji, jak: (1) (11), (11) (11) (11), ((11) (11)) (11), ((111) (1)) (1). Kombinacje będą również nazywane przedmiotami, a przyjęty na początku przedmiot myślowy 1 będzie nazywany przedmiotem prostym. Dodajemy teraz drugi prosty przedmiot myślowy i oznaczamy go za pomocą znaku = (równy). Dalej tworzymy kombinacje tych dwóch przedmiotów prostych, jak 1=, 11=, (1) $(=1)(===)$. Mówimy, że kombinacja $a$ przedmiotów prostych 1 , = różni się od kombinacji $b$ tych przedmiotów, kiedy różnią się one rodzajem i kolejnością kombinacji albo wyborem i występowaniem przedmiotów 1, =, tzn. kiedy $a$ i $b$ nie są identyczne. Teraz wyobrażamy sobie podział kombinacji owych dwóch prostych przedmiotów na dwie klasy, klasę istniejących i klasę nieistniejących: każdy przedmiot, który należy do klasy istniejących, jest różny od każdego przedmiotu, który należy do
} 
Przykładem przedmiotu myślowego nieistniejącego jest - przy rozbudowanym systemie znaków (przedmiotów myślowych) pierwotnych i przyjętej przez Hilberta aksjomatyce, będącej fragmentem aksjomatyki liczb naturalnych - np. liczba naturalna, której następnik równa się jeden9. To, do której klasy przedmiotów myślowych -istniejących czy nieistniejących - zaliczony jest przedmiot złożony odpowiadający formule złożonej ze znaków oznaczających odpowiednie proste przedmioty składowe, ma być wyznaczone przez przyjmowaną aksjomatykę ${ }^{10}$. Hilbert wykorzystał ten podział w istotny sposób w próbnym projekcie dowodu niesprzeczności arytmetyki liczb naturalnych, a dokładniej w szkicu dowodu niesprzeczności aksjomatyki będącej skromnym fragmentem aksjomatyki arytmetyki liczb naturalnych.

Dla obecnych rozważań istotne jest, że w pracy zapowiadającej program formalizmu Hilbert odwołuje się do ontologii. Co więcej, widać w niej już zapowiedź jednego ze współczesnych stanowisk w zakresie ontologii matematyki. Fakt, że aksjomatyka wyznacza podział przedmiotów na istniejące i nieistniejące, sprawia, że Hilbert $\mathrm{w}$ istocie relatywizuje istnienie matematyczne do przyjmowanej aksjomatyki. Odwołując się do wyżej podanego przykładu, można powiedzieć, że to, czy istnieje (matematycznie), czy też nie istnieje (matematycznie) liczba naturalna, której następnik jest równy jeden, zależy od przyjętej aksjomatyki. Przy pewnych zbiorach aksjomatów przedmiot ten będzie należał do klasy przedmiotów nieistniejących, przy innych - do klasy przedmiotów istniejących. Ostatecznie zatem to Hilbert jest tym matematykiem, który zrelatywizował istnienie matematyczne do aksjomatyki.

Można też w tym miejscu udzielić odpowiedzi na pytanie, czy Hilbertowski przedmiot myślowy to przedmiot intencjonalny, czy też „element” myślenia. Przeciw tej drugiej możliwości przemawia to, że w klasie przedmiotów

klasy nieistniejących. Każda kombinacja dwóch prostych przedmiotów 1, = należy do jednej z tych klas. Kiedy $a$ jest kombinacją dwóch podstawowych przedmiotów 1, =, to za pomocą $a$ oznaczamy również wypowiedź, że $a$ należy do klasy [przedmiotów] istniejących, a przy pomocy $\bar{a}$ wypowiedź, że $a$ należy do klasy [przedmiotów] nieistniejących. Określamy $a$ jako wypowiedź prawdziwą, kiedy a należy do klasy [przedmiotów] istniejących; natomiast $\bar{a}$ nazywa się wypowiedzią prawdziwą, kiedy a należy do klasy [przedmiotów] nieistniejących. Stwierdzenia $a$ i $\bar{a}$ tworzą sprzeczność" (Hilbert 1905: 181).

9 Zero nie jest tutaj przez Hilberta zaliczone do zbioru liczb naturalnych (zbiór ten nazywa zbiorem nieskończonym).

${ }^{10}$ „Kiedy chce się badać według przedstawionych wyżej zasad określony system (zbiór) aksjomatów, trzeba podzielić kombinacje przedmiotów prostych na dwie klasy: istniejących i nieistniejących, przy czym aksjomatom przypada rola przepisów, które musi ów podział spełniać. Główna trudność będzie polegała na rozpoznaniu możliwości rozdzielenia wszystkich przedmiotów do dwóch klas - przedmiotów istniejących i przedmiotów nieistniejących" (Hilbert 1905: 184). 
myślowych Hilbert wprowadza - zrelatywizowaną do przyjmowanej aksjomatyki - podklasę przedmiotów nieistniejących. Coś, co jest „elementem”, „fragmentem” myślenia zdaje się istnieć. Natomiast przedmiot intencjonalny, ten, o którym się myśli, istnieć nie musi, jak chociażby Smok Wawelski. Należy zatem interpretować Hilbertowski przedmiot myślowy jako przedmiot intencjonalny i nie traktować jego wypowiedzi z 1904 r. jako przejawu powrotu do konceptualizmu i konstruktywizmu.

Warto przy okazji zauważyć, że klasa przedmiotów matematycznych Hilberta jest bardzo bogata. Najogólniej rzecz biorąc, elementarnym przedmiotem matematycznym jest każdy przedmiot oznaczany przez znak elementarny. Oprócz znaku liczby jeden i znaku równości Hilbert wprowadza cały szereg innych znaków elementarnych, np. na oznaczenie funkcji, zbioru, zbioru nieskończonego. Oczywiście, znaki te można zestawiać, oznaczają one wtedy odpowiednie kombinacje przedmiotów elementarnych. Istotne jest to, że np. relacje - chociażby „=" - traktowane są jako przedmioty matematyczne.

Podsumowując, można stwierdzić, że wykład Hilberta z 1904 r., będący wyraźną zapowiedzią formalizmu w podstawach matematyki, nie antycypuje nominalizmu metodologicznego charakterystycznego dla jego dojrzałego formalizmu. Hilbert wyraźnie mówi o znakach i odpowiadających im przedmiotach, które nie są eliminowane czy też traktowane jako nieistotne. Jednocześnie relatywizuje istnienie matematyczne do przyjmowanej aksjomatyki. Nie ma tutaj powrotu do konceptualizmu i konstruktywizmu.

\section{ANTYPLATONIZM}

Interesujące wydaje się pytanie o stanowisko Hilberta we wczesnym okresie kształtowania się jego programu badań podstaw matematyki wobec platonizmu. Platonizm był przecież głównym założeniem ontologicznym dwóch uczonych, aktywnych we wczesnej fazie działalności Hilberta, którzy w znaczny sposób rozwinęli badania podstaw matematyki. Chodzi oczywiście o Cantora i Fregego. W świetle przedstawionych wyżej wyników można twierdzić, że Hilbert powinien być „z natury” uprzedzony do stanowiska skrajnego realizmu w ontologii matematyki. Okazuje się, że rzeczywiście w 1904 r. Hilbert odrzucał stanowisko platonizmu, ale dobrze ugruntowana przyczyna tego stanu rzeczy leżała gdzie indziej.

Skrajny realizm w ontologii matematyki był w przypadku Cantora i Fregego powiązany z redukcjonizmem. Obydwaj uważali, że matematykę można sprowadzić do pewnej dyscypliny podstawowej - teorii mnogości czy też logiki 
(z pojęciem zbioru). Znaczyło to tyle, że wszystkie przedmioty matematyki można budować za pomocą podstawowych obiektów tych dyscyplin podstawowych, tzn. za pomocą zbiorów (klas). Ponieważ zbiór (klasę) - ów elementarny budulec - pojmowali po platońsku, to w konsekwencji stawali w ontologii matematyki na stanowisku skrajnego realizmu.

Otóż w 1904 r. Hilbert był przekonany, że zarysowany wyżej program redukcjonistyczny jest niewykonalny. Powodem były znane w środowisku niemieckim od 1899 r. antynomie teoriomnogościowe. W 1899 r. Cantor poinformował środowisko o odkrytej przez siebie antynomii największej liczby porządkowej. Na początku XX w. całą sytuację pogorszyło jeszcze odkrycie antynomii Russella. Hilbert w 1904 r. stał na stanowisku, że program logicyzmu Fregego jest nie do uratowania ${ }^{11}$. Uważał też, że podjęte przez Cantora w 1899 r. działania zabezpieczające przed antynomiami są niewystarczające ${ }^{12}$. Rzecz jasna, nie było wtedy jeszcze „poprawionej” wersji logicyzmu Russella i Whiteheada ani aksjomatyki teorii mnogości Zermela, które eliminowały antynomie. $Z$ drugiej strony trzeba dodać, że usuwały one tylko znane antynomie, nie dawały jednak żadnej gwarancji niewystąpienia w teorii mnogości antynomii dotychczas nieznanych.

To właśnie były powody, dla których Hilbert nie chciał nadbudowywać całej matematyki na logice (z pojęciem klasy) czy też na teorii mnogości. Obydwa systemy - a przede wszystkim ich podstawowe „składowe”, klasy i zbiory - były pojmowane przez ich twórców skrajnie realistycznie. Dlatego Hilbert swój sceptycyzm wobec wielkich systemów redukcjonistycznych rozszerzał na stojącą za nimi realistyczną ontologię.

${ }^{11}$ „G. Frege stawia sobie zadanie ugruntowania praw arytmetyki za pomocą środków logiki [...] Zasłużył się on właściwym rozpoznaniem istotnych własności liczb naturalnych i znaczenia wnioskowania za pomocą zasady indukcji zupełnej. Ponieważ jednak wierny swojemu planowi przyjmuje m.in. jako podstawową zasadę, że pojęcie (zbiór) jest zdefiniowane i natychmiast możliwe do zastosowania, kiedy tylko dla każdego przedmiotu określone jest, czy podpada on pod owe pojęcie, czy też nie, i przy tym nie poddaje pojęcia »każdy« żadnemu ograniczeniu, naraża się właśnie na te teoriomnogościowe paradoksy, które m.in. mają swe źródło w pojęciu zbioru wszystkich zbiorów, i które, jak mi się wydaje, pokazują, że ujęcia i metody badania logiki, wprowadzone przez Fregego, nie spełniają ścisłych wymagań, które stawia teoria mnogości. Uniknięcie takich sprzeczności i wyjaśnienie owych paradoksów musi być od początku głównym celem badań nad pojęciem liczby” (Hilbert 1905: 175).

12 „G. Cantor odczuł ową sprzeczność i wyraził swe odczucie przez rozróżnienie zbiorów »konsystentnych « $\mathrm{i}$ »niekonsystentnych «. Ponieważ jednak, według mnie, nie przedstawił on dla tego podziału żadnego ostrego kryterium, muszę określić jego ujęcie jako pozostawiające jeszcze pole manewru subiektywnej ocenie i dlatego niezapewniające obiektywnego bezpieczeństwa” (Hilbert 1905: 176). 
Wypada zaznaczyć, że w miejsce redukcjonistycznego Hilbert zaproponował inny sposób budowy matematyki, który nazywa aksjomatycznym. Najogólniej charakteryzuje go jako równoczesną budowę matematyki (arytmetyki) i logiki. Polega on na tym, że aksjomatyką obejmuje się równocześnie fragment arytmetyki liczb naturalnych i fragment logiki. Następnie przedstawia się dowód niesprzeczności tej aksjomatyki, a potem jej rozszerzenie o nowe aksjomaty arytmetyczne i logiczne. Kolejnym krokiem jest dowód niesprzeczności i kolejne rozszerzenie aksjomatyki aż po zamierzony dowód niesprzeczności pełnej aksjomatyki arytmetyki liczb naturalnych (z odpowiednimi aksjomatami logicznymi) ${ }^{13}$. Trzeba dodać, że wspomniana logika zawiera elementy teorii mnogości.

Tak więc zasadniczym powodem, dla którego Hilbert dystansował się, przynajmniej w latach 1899-1904, od skrajnego realizmu w ontologii matematyki, był nie tyle dawny konstruktywizm, ile aktualny stan badań w kwestii podstaw matematyki, czyli stwierdzenie antynomii.

\section{ZAKOŃCZENIE}

Prześledzono tu przemiany w Hilbertowskiej ontologii matematyki w latach 1891-1904. Na początku Hilbertowi była bliska ontologia Dedekinda. Zawierała się ona $\mathrm{w}$ konstruktywistycznej tezie: liczby naturalne są wytworem podmiotu poznającego, z nich buduje on wszystkie obiekty matematyki czystej. Wskazano, że Hilbert łączył konstruktywizm z konceptualizmem. Natomiast obiektami geometrii były zdaniem Hilberta przedmioty zawarte w przestrzeni fizycznej.

Ta dualistyczna ontologia została ujednolicona w latach 1899-1900. Przedmiotami matematyki - w tym geometrii - miały być wszystkie przedmioty spełniające warunki nałożone na nie przez aksjomaty. Można to jeszcze inaczej wyrazić: syntaksa teorii matematycznych nie ma zamierzonego modelu. Przypuszczenie, że już tu rodzi się późniejszy nominalizm metodologiczny, zostało

\footnotetext{
${ }^{13}$ „Jestem przekonany, że wszystkie wymienione trudności dają się przezwyciężyć i że można dojść do ścisłego i w pełni zadawalającego pojęcia liczby [naturalnej] i to dzięki zastosowaniu metody, którą nazywam aksjomatyczną, a której podstawową ideę chcę poniżej krótko rozwinąć. Arytmetykę określa się jako część logiki i zazwyczaj zakłada się przy ugruntowaniu arytmetyki podstawowe pojęcia logiczne. Jednak przy uważnej analizie zauważymy, że przy wprowadzaniu praw logiki używa się już pewnych podstawowych pojęć arytmetycznych, np. pojęcia zbioru i częściowo pojęcia liczby. W ten sposób popadamy w trudności i dlatego dla uniknięcia paradoksów potrzebne jest częściowo równoczesne rozwijanie praw logiki i arytmetyki” (Hilbert 1905: 176).
} 
odrzucone w wyniku analizy referatu Hilberta z 1904 r. Przedmiotami matematyki są Gedankendinge, czyli przedmioty intencjonalne. To stanowisko nie łączy się z konceptualizmem ani z konstruktywizmem z 1891 r. Hilbert odrzuca też skrajny realizm w ontologii matematyki. Przyczyną nie jest dawna skłonność do konceptualizmu, lecz odkrywane kolejno antynomie teoriomnogościowe.

Hilbert formułuje też kryterium istnienia matematycznego: przedmiot istnieje (matematycznie) wtedy i tylko wtedy, gdy jest niesprzeczny. Przy czym istnienie obiektu matematycznego jest u niego w 1904 r. zrelatywizowane do aksjomatyki.

Należy zauważyć, że stanowisko Hilberta w zakresie ontologii matematyki ulegało istotnym przemianom. Jak zaznaczono, mimo że jego dokonania w zakresie podstaw matematyki w latach 1899-1904 zdecydowanie przygotowywały późniejszy program formalizmu, to $\mathrm{w}$ ontologii matematyki był on jeszcze wówczas daleki od nominalizmu metodologicznego. Paradoksalne wydaje się zaś to, że pierwotnym stanowiskiem Hilberta w tym zakresie był konceptualizm związany z konstruktywizmem, który w czasie głośnego sporu $\mathrm{z}$ Brouwerem $\mathrm{w}$ latach dwudziestych był filozoficzną podstawą intuicjonistycznych ataków na koncepcję podstaw matematyki twórcy formalizmu.

\section{BIBLIOGRAFIA}

Dedekind R. (1888), Was sind und was sollen die Zahlen?, Braunschweig: Vieweg.

Hilbert D. (1899/1968), Grundlagen der Geometrie, Stuttgart: Teubner.

Hilbert D. (1900a), Über den Zahlbegriff, „Jahresbericht der Deutschen MathematikerVereinigung" 8, 180-184.

Hilbert D. (1900b), Mathematische Probleme, „Nachrichten von der Gesellschaft der Wissenschaften zu Göttingen. Mathematisch-Physikalische Klasse” 3, 253-297.

Hilbert D. (1905), Über die Grundlagen der Logik und der Mathematik [w:] Verhandlungen des Dritten Internationalen Mathematiker-Kongresses in Heidelberg vom 8. bis 13. August 1904, A. Krazer (Hrsg.), Leipzig: Teubner, 174-185.

Hilbert D. (1926), Über das Unendliche, „Mathematische Annalen” 95, 161-190.

Hilbert D. (1931), Die Grundlegung der elementahren Zahlenlehre, „Mathematische Annalen" 104, 485-494.

Hilbert D. (2004), Projektive Geometrie [w:] David Hilbert's Lectures on the Foundations of Geometry 1891-1902, M. Hallett, U. Majer (eds.), Berlin: Springer, 21-55. 